\title{
Protector Device
}

National Cancer Institute

\section{Source}

National Cancer Institute. Protector Device. NCI Thesaurus. Code C50125.

A device or attachment designed to shield something from harm. 